\title{
Emotional Intelligence on Students' Learning Achievement in High School of Makassar, Indonesia
}

\author{
Muhammad Makbul \\ Institut Sains dan Teknologi An-Nuriyah Makassar, Indonesia \\ makbulm013@gmail.com \\ Ismail Suardi Wekke \\ Institut Agama Islam Negeri (IAIN) Sorong, Indonesia \\ Asosiasi Dosen Insan Cita Indonesia, Indonesia \\ The Jusuf Kalla Research Center for Cultural Studies, Universitas Muslim Indonesia \\ iswekke@gmail.com \\ Dewi Saputri Sussang \\ UIN Alauddin Makassar, Indonesia \\ dewiq@gmail.com \\ Amin Rais \\ UIN Alauddin Makassar, Indonesia \\ aminraisamr@gmail.com \\ Nurlathifah Thulfitrah Baharuddin \\ UIN Alauddin Makassar, Indonesia \\ nurlathifahtuhulfitrahbz@gmail.com \\ Matahari Muhizar Manaf \\ Universitas Pendidikan Muhammadiyah Sorong, Indonesia \\ mmmanaf@gmail.com
}

\begin{abstract}
The objectives of this research to describe level of students' emotional intelligence, learning achievement's, and the influence of emotional intelligence on student learning achievements. This type of quantitative research consists of two variables of emotional intelligence as the independent variable and learning achievements of physics learning achievements as dependent on the ex-post facto method. Proportional cluster random sampling is a data collection method used to collect 135, a questionnaire instrument with a Likert scale to collect emotional intelligence data and a documentation format used to collect Physics learning achievements. The data obtained were analyzed by descriptive and inferential statistics. The conclusion of this study is that the emotional intelligence of students is in the moderate category with a presentation of $65 \%$ with a frequency of 88 students.
\end{abstract}

\section{Keywords:}

Emotional Intelligence, Physics Learning Achievements 


\section{Introduction}

The National Education System, article 3 explains that the function of national education is to develop capabilities and shape the character and civilization of a dignified nation to educate the nation's life; as well as the orientation of national education in an effort to develop the potential of students to become human beings who believe and fear God Almighty, have noble character, are healthy, knowledgeable, capable, creative, independent, and become democratic and responsible citizens (Andriani, Asna 2014)

Student learning achievements are an achievement obtained by students which include aspects of cognition, psychomotor, and affection, this is very important in the life and development of students in an effort to pass important achievements in the learning process, learning achievements are also a reference for assessing the progress of students in carrying out learning, whether the process they go through is as expected or not, so that this can be taken into consideration in future learning plans. (Frisdiantara, Indawati, \& Wekke, 2017).

After conducting initial observations, problems were found in student learning achievements, namely the inequality of student learning achievements for Physics subjects, namely the condition that there were students who had relatively low physics learning achievements and some were too high. From the results of interviews conducted, information was obtained that some of the attitudes shown by students were varied, some were indifferent in learning, some were not. While interviews conducted with students revealed that this was because some felt they had no motivation in learning, some felt confused about problems outside of learning so that when learning began, they admitted that they could not focus while learning was taking place. (Neneng Handriani 2020) Analyzing the descriptions of the research subjects, the researcher assumes that the problems experienced by students are because they experience problems in the stages of development that are generally felt in adolescence, namely changes, and the ability to recognize and manage emotions (Makbul, 2018).

Regarding the problem of these symptoms, this is related to Daniel Goleman's theory which is related to emotional intelligence, so the researcher tries to find out the factors that reveal the influence of emotional intelligence on the learning achievements of physics students in SMAN 5 of Makassar. Regarding the novelty in this research, it lies in the scope and location of the research that specifically conducts research in SMAN 5 of Makassar with the independent variable of emotional intelligence while the dependent variable is the student's physics learning achievements, according to the researcher's search this title has never been done in SMAN 5 of Makassar, so the researcher interested in trying to uncover the problem of the influence of emotional intelligence on student learning achievements in SMAN 5 of Makassar.

\section{Methods}

The type of research used in this study is quantitative research because it consists of two variables, namely emotional intelligence with students' learning achievements in physics.(Yusuf, M., \& Wekke, I. S. 2020). This type of research uses the ex-post facto method in this study, emotional intelligence as an independent variable and learning achievements of physics as the dependent variable. stated explicitly, to then be linked as an influence study or predicted if the independent variable has a certain influence with the dependent variable. (Defila 2018).

Respondents in this study amounted to 135 people who were obtained using proportional cluster random sampling, to collect data using a questionnaire instrument with a Likert scale in the form of a questionnaire that had gone through the instrument validation stage then the questionnaire was filled in by each student while the documentation format was used to collect the results. learn Physics students. (Muzdalifah 2018) The data obtained were analyzed using descriptive and inferential statistics by performing the $\mathrm{F}$ test.

\section{Results and Discussion}

The results of the research and the following discussion will describe the findings in the research, both descriptive analysis and inferential analysis, then describe the discussion in accordance with the findings on the data that has been analyzed. Based on the results of research on 135 students who were selected as research samples, the results of the emotional intelligence of students are presented as follows: 
Table 1.Overview of Students' Emotional Intelligence

\begin{tabular}{|c|c|c|c|c|}
\hline \multicolumn{5}{|c|}{ Descriptives } \\
\hline & & & Statistics & Std. Error \\
\hline \multirow{13}{*}{$\begin{array}{l}\text { Emotional } \\
\text { Intelligence }\end{array}$} & Mean & & 80.56 & 0.708 \\
\hline & \multirow{2}{*}{$\begin{array}{l}95 \% \text { Confidence } \\
\text { Interval for Mean }\end{array}$} & Lower Bound & 79.16 & \\
\hline & & Upper Bound & 81.96 & \\
\hline & \multicolumn{2}{|l|}{ 5\% Trimmed Mean } & 80.51 & \\
\hline & \multicolumn{2}{|l|}{ Median } & 80.00 & \\
\hline & \multicolumn{2}{|l|}{ Variance } & 67,681 & \\
\hline & \multicolumn{2}{|l|}{ Std. Deviation } & 8,227 & \\
\hline & \multicolumn{2}{|l|}{ Minimum } & 60 & \\
\hline & \multicolumn{2}{|l|}{ Maximum } & 101 & \\
\hline & \multicolumn{2}{|l|}{ Range } & 41 & \\
\hline & \multicolumn{2}{|c|}{ Interquartile Range } & 12 & \\
\hline & \multicolumn{2}{|l|}{ Skewness } & 0.047 & 0.209 \\
\hline & \multicolumn{2}{|l|}{ Kurtosis } & -0.319 & 0.414 \\
\hline
\end{tabular}

Determination of the category of emotional intelligence data of students in SMA Negeri 5 of Makassar in this study refers to the categorization of levels by classifying subjects into 3 categories from Saifuddin Azwar.[6] The table of emotional intelligence categories is as follows:

Table 2. Categorization of Emotional Intelligence

\begin{tabular}{ccccc}
\hline Category Limit & Interval & Frequency & Percentage & Information \\
\hline $\mathbf{X}<(\boldsymbol{\mu - 1 . 0 \sigma})$ & $\mathrm{X}<72,336$ & 22 & $16 \%$ & Low \\
\hline$(\boldsymbol{\mu - 1 . 0 \sigma}) \mathbf{X}<(\boldsymbol{\mu}+\mathbf{1 . 0})$ & $69.12 \leq \mathrm{X}<88.790$ & 88 & $65 \%$ & Medium \\
\hline$(\boldsymbol{\mu}+\mathbf{1 . 0 \sigma})<\mathbf{X}$ & $88,790 \mathrm{X}$ & 25 & $19 \%$ & High \\
\hline amount & & $\mathbf{1 3 5}$ & $\mathbf{1 0 0} \%$ & \\
\hline
\end{tabular}

Based on the data in the table, the emotional intelligence of students at SMA Negeri 5 Makassar, it is concluded that the emotional intelligence of students is in the medium category with a presentation of $65 \%$ with a frequency of 88 students.

This indicates that students answer the questionnaire given which shows students generally experience related problems, recognize their own emotions, manage emotions, motivate themselves, recognize other people's emotions and build relationships. This is closely related to socio-emotional development, environmental conditions and the form of guidance carried out by parents, the environment and the school regarding these conditions. (Ismail, Wekke, Dinesh Kumar, Pandi Selvam, Shankar, \& Nguyen, 2019).

Furthermore, based on the results of research on 135 students who were selected as samples and have filled out a questionnaire, the research results of the emotional intelligence of students are presented as follows: 
Table 3. Overview of Student Learning achievements

\begin{tabular}{|c|c|c|c|c|}
\hline \multicolumn{5}{|c|}{ Descriptive } \\
\hline & & & Statistics & Std. Error \\
\hline \multirow{14}{*}{$\begin{array}{l}\text { Physics } \\
\text { Learning } \\
\text { Results }\end{array}$} & mean & & 80.28 & 0.930 \\
\hline & \multirow{3}{*}{$\begin{array}{l}\text { 95\% Confidence } \\
\text { Interval for Mean }\end{array}$} & Lower & 78.44 & \\
\hline & & Bound & & \\
\hline & & Upper & 82.12 & \\
\hline & \multicolumn{2}{|l|}{ 5\% Trimmed Mean } & 8059 & \\
\hline & \multicolumn{2}{|l|}{ median } & 83.00 & \\
\hline & \multicolumn{2}{|l|}{ Variance } & 116.831 & \\
\hline & \multicolumn{2}{|l|}{ Std. Deviation } & 10,809 & \\
\hline & \multicolumn{2}{|l|}{ Minimum } & 58 & \\
\hline & \multicolumn{2}{|l|}{ Maximum } & 96 & \\
\hline & \multicolumn{2}{|l|}{ Range } & 38 & \\
\hline & \multicolumn{2}{|c|}{ Interquartile Range } & 20 & \\
\hline & \multicolumn{2}{|l|}{ Skewness } & -0.333 & 0.209 \\
\hline & \multicolumn{2}{|l|}{ Kurtosis } & -1.107 & 0.414 \\
\hline
\end{tabular}

Furthermore, the determination of the category of student learning achievements data at SMA Negeri 5 Makassar in this study also refers to the categorization of levels by classifying subjects into 3 categories from Saifuddin Azwar The table of emotional intelligence categories is as follows:

Table 4. Categorization of Emotional Intelligence

\begin{tabular}{ccccc}
\hline Category Limit & interval & Frequency & Percentage & Information \\
\hline $\mathbf{X}<(\boldsymbol{\mu - 1 . 0 \sigma})$ & $X<69,473$ & 20 & $15 \%$ & Low \\
\hline$(\boldsymbol{\mu - 1 . 0 \sigma}) \mathbf{X}<(\boldsymbol{\mu}+\mathbf{1 . 0})$ & $69.473 X<91.09$ & 80 & $59 \%$ & Medium \\
\hline$(\boldsymbol{\mu}+\mathbf{1 . 0 \sigma})<\mathbf{X}$ & $91.09 X$ & 35 & $26 \%$ & High \\
\hline amount & & $\mathbf{1 3 5}$ & $\mathbf{1 0 0} \%$ & \\
\hline
\end{tabular}

Based on the data in the table, student learning achievements at SMA Negeri 5 Makassar, it is concluded that student learning achievements are in the medium category with a presentation of $59 \%$ with a frequency of 80 students. This gives an indication that the results of the learning process of students in this case the exams carried out by Physics subject teachers are still in the medium category, this result is influenced by many things, both internal and external influences (Theresia Evy Yulianty Nadeak 2020)Before the regression test is carried out, a prerequisite test is first carried out, namely the normality test, this test aims to determine whether the data is further analyzed using parametric or non-parametric tests (Tukwain, Fatimah, \& Wekke, 2018).

The data is normally distributed if $\mathrm{sig}>=0.05$ and vice versa, the data is said to be not normally distributed if $\operatorname{sig}<=0.05 .[8]$ 
Table 5. Data Normality Test

One-Sample Kolmogorov-Smirnov Test

\begin{tabular}{lll}
\hline \multicolumn{2}{c}{ One-Sample Kolmogorov-Smirnov Test } \\
\hline $\mathbf{N}$ & \multicolumn{1}{c}{ Unstandardized Residual } \\
\hline $\begin{array}{l}\text { Normal } \\
\text { Parameters, b }\end{array}$ & mean & 135 \\
\cline { 2 - 3 } & $\begin{array}{l}\text { Std. } \\
\text { Deviation }\end{array}$ \\
\hline $\begin{array}{l}\text { Most Extreme } \\
\text { Differences }\end{array}$ & Absolute & 0.0000000 \\
\cline { 2 - 3 } & Positive & 0.046 \\
\cline { 2 - 3 } & Negative & -0.046 \\
\hline Test Statistics & 0.043 \\
\hline asymp. Sig. (2-tailed) & 0.046 \\
\hline a. Test distribution is Normal. & $, 200 \mathrm{c}, \mathrm{d}$ \\
\hline b. Calculated from data. \\
\hline \multicolumn{2}{l}{ c. Lilliefors Significance Correction. } \\
\hline d. This is a lower bound of the true significance. \\
\hline
\end{tabular}

From the SPSS test in table 5, the sig value is obtained. $0.200>=0.05$ so that the data is said to be normally distributed so that the test is carried out using parametric statistical tests.

After performing the normality test, it is continued with the linearity test, which aims to determine the relationship formed between the independent variable and the dependent variable partially and linearly. Linearity test is used to determine whether the data is in accordance with the linear line or not. linearity test criteria with processed SPSS version 25 , namely if sig $>0.05$ then the data is linear and if sig $<0.05$ then the data is not linear.

Table 6. Data Linearity Test

ANOVA Table

\begin{tabular}{|c|c|c|c|c|c|c|c|}
\hline & & & $\begin{array}{l}\text { Sum of } \\
\text { Squares }\end{array}$ & df & $\begin{array}{c}\text { Mean } \\
\text { Square }\end{array}$ & $\mathrm{F}$ & Sig. \\
\hline \multirow{5}{*}{$\begin{array}{l}\text { Physics } \\
\text { Learning } \\
\text { achievements } \\
* \text { Emotional } \\
\text { Intelligence }\end{array}$} & \multirow{3}{*}{$\begin{array}{l}\text { Between } \\
\text { Groups }\end{array}$} & (Combined) & 10946.381 & 33 & 331,709 & 7,115 & 0.000 \\
\hline & & linearity & 8452,844 & 1 & 8452,844 & 181,302 & 0.000 \\
\hline & & $\begin{array}{l}\text { Deviation } \\
\text { from } \\
\text { Linearity }\end{array}$ & 2493,537 & 32 & 77,923 & 1,671 & 0.283 \\
\hline & \multicolumn{2}{|c|}{ Within Groups } & 4708,923 & 101 & 46,623 & & \\
\hline & \multicolumn{2}{|l|}{ Total } & 15655,304 & 134 & & & \\
\hline
\end{tabular}

From the results of the linearity test in table 6, according to the results of SPSS version 25 processing, the value in the deviation from linearity column is $0.283>0.05$, so the linear data can be concluded that emotional intelligence has a linear relationship with learning achievements (Rambe, 2020).

The next test is the regression test which is used to determine the relationship between variables that predict the value of the emotional intelligence variable and learning achievements through the regression equation with the following results:

Table 7. Simple Regression Test

\begin{tabular}{|c|c|c|c|c|c|}
\hline \multicolumn{6}{|c|}{ Coefficients } \\
\hline \multirow[t]{2}{*}{ Model } & \multicolumn{2}{|c|}{$\begin{array}{l}\text { Unstandardized } \\
\text { Coefficients }\end{array}$} & \multirow{2}{*}{$\begin{array}{c}\text { Standardized } \\
\text { Coefficients }\end{array}$} & \multirow[t]{2}{*}{$\mathrm{t}$} & \multirow[t]{2}{*}{ Sig. } \\
\hline & B & $\begin{array}{l}\text { Std. } \\
\text { Error }\end{array}$ & & & \\
\hline 1 (Constant) & 2,504 & 6,258 & & 0.400 & 0.690 \\
\hline $\begin{array}{l}\text { Emotional } \\
\text { Intelligence }\end{array}$ & 0.965 & 0.077 & 0.735 & 12,494 & 0.000 \\
\hline
\end{tabular}




\section{a. Dependent Variable: Physics Learning achievements}

Table 8. Regression Equation

\begin{tabular}{ccc}
\hline Equation & $\boldsymbol{a}$ (Constant) & b (Regression Coefficient) \\
\hline X1-Y & 2,504 & 0.965
\end{tabular}

The regression line equation is written in the form $=+b X$, this equation shows the direction of the relationship between $\mathrm{X} 2$ and $\mathrm{Y}$ whether it is positive or negative. Based on the results of SPSS 25 analysis in the coefficient table above, the constant value is $=-30.52$ and the regression coefficient of 1.336 so that the regression equation is: $=2.504+0.965$ X. (Bahriani, M. M. D 2020)

The purpose of this equation is when emotional intelligence increases by one unit, it will increase by 0.965 units, and if there is a decrease in one unit of the academic supervision competency variable, the education quality variable will decrease by 0.965 . A positive coefficient means that the relationship between academic supervision competence and the quality of education is increasing (Purnama, Nguyen, ThuyTo Nguyen, Huynh, \& Wekke, 2019).

The next test is hypothesis testing to determine the effect of independent variables on the dependent variable, hypothesis testing carried out here is hypothesis testing between $\mathrm{X}$ and $\mathrm{Y}$ variables. (Mujahid, Minsih, Ghafur, \& Wekke, 2019). The formulation of the hypothesis in this study is as follows:

- $\mathrm{H}_{1}$ : There is a positive and significant influence of emotional intelligence $(\mathrm{X})$ on students' physics learning achievements (Y).

- $\mathrm{H}_{0}$ : There is no positive and significant effect of emotional intelligence $(\mathrm{X})$ on students' physics learning achievements (Y).

Table 9. Reference Interpretation of Product Moment " $r$ " Value

\begin{tabular}{cc}
\hline Coefficient Interval & Relationship Level \\
\hline $\mathbf{0 . 0 0}-\mathbf{0 . 1 9 9}$ & Very low/no relationship \\
\hline $\mathbf{0 . 2 0}-\mathbf{0 . 3 9 9}$ & Low \\
\hline $\mathbf{0 . 4 0}-\mathbf{0 . 5 9 9}$ & Moderate/enough \\
\hline $\mathbf{0 . 6 0}-\mathbf{0 . 7 9 9}$ & Strong \\
\hline $\mathbf{0 . 8 0}-\mathbf{1 0 0}$ & Very strong \\
\hline
\end{tabular}

Table 10. Hypothesis Test

\begin{tabular}{ccccc}
\hline Model & R & R Square & $\begin{array}{c}\text { Adjusted R } \\
\text { Square }\end{array}$ & $\begin{array}{c}\text { Std. Error of the } \\
\text { Estimate }\end{array}$ \\
\hline $\mathbf{1}$ &, $735 \mathrm{a}$ & 0.540 & 0.536 & 7,359 \\
\hline
\end{tabular}

From the Model Summary table, the value of $\mathrm{R}^{2}=0.540$ means that the independent variable of emotional intelligence is able to predict the value of the dependent variable on physics learning achievements by $54 \%$, the remaining $46 \%$ is explained by other factors. The output above also explains that the $\mathrm{R}$ number is $0.735_{\mathrm{a}}$ so it can be concluded that there is a relationship between emotional intelligence and students' physics learning achievements.

Based on the results of processing with SPSS 25 obtained $t$ count of 12.494 and the value of $t$ table can be seen in the statistical table for significance $=0.05$. The results obtained for $t$ table $(0.05 ; 133)=1.66$ Because $t$ count $=$ $12.494>1.66$. The significance value is 0.000 . Significance value $<0.05(0.000<0.05)$, then $\mathrm{H} 1$ is accepted and $\mathrm{H} 0$ is rejected, so the conclusion from this study is that there is a significant positive effect of emotional intelligence on student learning achievements in SMAN 5 of Makassar. These results answer the theoretical assumptions that have been compiled in the hypothesis about the influence of emotional intelligence on student learning achievements. (Tadjuddin, Elfiah, Meriyati, Wekke, \& Saregar, 2019).

Referring to these results, it can be said that to improve learning achievements, one of the efforts that can be done is to provide guidance for students to increase their emotional intelligence considering aspects of emotional intelligence which include the ability of students to; recognize your own emotions, manage your emotions, motivate yourself, recognize the emotions of others and build relationships.( Lubis, M. A., Embi, M. A., Wekke, I. S., Ghani, K. A., \& Sulaiman, S. 2010).

Its relevance to learning achievements is that students who enjoy the climate of the classroom atmosphere, are able to solve their emotional problems before starting learning, have good internal motivation and are able to socialize 
well in class tend to have better learning achievements than those who do not (Wekke, Aghsari, Evizariza, Junaidi, \& Harun, 2018). The novelty in this study is related to the case experienced in SMAN 5 of Makassar, which shows that moderate intelligence affects learning achievements, especially if emotional intelligence is high.

\section{Conclusion}

The conclusion of this study is that the emotional intelligence of students is in the moderate category with a presentation of $65 \%$ with a frequency of 88 students. Student learning achievements are in the medium category with a presentation of 59\% with a frequency of 80 students, that there is a positive and significant influence of emotional intelligence (X) on students' physics learning achievements in SMAN 5 of Makassar.

\section{Reference}

Andoko Ageng Setyawan 2018 Pengaruh Kecerdasan Emosional Terhadap Hasil Belajar Matematika Siswa Smk Kansai Pekanbaru JPPM 11 1 10-18

Andriani, Asna 2014 Kecerdasan Emosional dalam Peningkatan Prestasi Belajar, STAI Muhammadiyah Tulunggagung, Edukasi 211 23-27

Bahriani, M. M. D 2020 Pengaruh Pemberian Penguatan (Reinforcement) terhadap Prestasi Belajar Peserta Didik dalam Bidang Studi Pendidikan Agama Islam di SMP Negeri Makassar. Journal Mistar 11 9-12

Defila 2018 Hubungan Kecerdasan Emosional dengan Hasil Belajar IPA Siswa SMP Negeri 1 Palu Jurnal Pendidikan Fisika Tadulako (JPFT) 22 29-35

Frisdiantara, C., Indawati, N., \& Wekke, I. S. (2017). Religiosity, competence and independence in forming the anticorruption attitude. Journal of Engineering and Applied Sciences, 12(7), 1701-1704. doi:10.3923/jeasci.2017.1701.1704

Hendra Sulistiawan 2019 Hubungan Efikasi Diri, Kecerdasan Emosional Dengan Minat Belajar Fisika Jurnal Pendidikan 4 1 43-48

Ismail, R., Wekke, I. S., Dinesh Kumar, A., Pandi Selvam, R., Shankar, K., \& Nguyen, P. T. (2019). Character reorganization and categorization using hybrid algorithms by scanned documents. International Journal of Engineering and Advanced Technology, 8(6 Special Issue 2), 943-948. doi:10.35940/ijeat.F1287.0886S219

Lubis, M. A., Embi, M. A., Wekke, I. S., Ghani, K. A., \& Sulaiman, S. (2010). Information and communication technology application on learning bahasa melayu among foreign students. Paper presented at the Advances in E-Activities, Information Security and Privacy - 9th WSEAS Int. Conference on E-Activities, EACTIVITIES'10, 9th WSEAS Int. Conference on Information Security and Privacy, ISP'10, 13-21.

M Makbul 2020 The Effect of Emotional Intelligence and Spiritual Intelligence on Learning Outcomes of Islamic Religion and Characteristics of Students at SMA Negeri 5 Makassar IJSSHR 4 588-595

Mujahid, I., Minsih, M., Ghafur, W. A., \& Wekke, I. S. (2019). Teaching and learning in inclusive classroom; case in elementary school. Journal of Advanced Research in Dynamical and Control Systems, 11(8 Special Issue), 557-568.

Muzdalifah 2018 Pengaruh Kecerdasan Intelektual, Kecerdasan Emosional, dan Kecerdasan Spiritual Terhadap Hasil Belajar IPA di Kabupaten Sinjai UNM Journal of Biological Education 12 149-154

Muzdalifah 2018 Pengaruh Kecerdasan Intelektual, Kecerdasan Emosional, dan Kecerdasan Spiritual Terhadap Hasil Belajar IPA di Kabupaten Sinjai UNM Journal of Biological Education 12 149-154

Neneng Handriani 2020 Hubungan Kecerdasan Intelektual Kecerdasan Emosional dan Kecerdasan Spiritual Terhadap Prestasi Belajar Fisika Gravity Edu: Jurnal Fisika, dan Pendidikan Fisika 31 2-3

Purnama, E. D., Nguyen, P., ThuyTo Nguyen, Q. L. H., Huynh, V. D. B., \& Wekke, I. S. (2019). Meeting industrial strategic requirements with the use of knowledge management tools. Test Engineering and Management, 81, 1131-1135.

Rambe, N. A. 2020. Hubungan Kecerdasan Emosional dengan Hasil Belajar Biologi Siswa Kelas X MIA MAN 3 Medan T.P. 2017/2018 Jurnal Pelita Pendidikan 62 90-94.

Tadjuddin, N., Elfiah, R., Meriyati, M., Wekke, I. S., \& Saregar, A. (2019). The interaction of children's early moral development process through a holistic approach. International Journal of Innovation, Creativity and Change, 8(9), 126-142.

Theresia Evy Yulianty Nadeak 2020 Pengaruh Kecerdasan Emosional dan Sikap Siswa terhadap Pemahaman Konsep Kimia SAP Susunan Artikel Pendidikan 52 169-176

Tukwain, S. M. F., Fatimah, F., \& Wekke, I. S. (2018). Religious expression in coastal area of muslim society west papua. Paper presented at the IOP Conference Series: Earth and Environmental Science, , 156(1) doi:10.1088/1755-1315/156/1/012033 
Wekke, I. S., Aghsari, D., Evizariza, E., Junaidi, J., \& Harun, N. (2018). Religion and culture encounters in misool raja ampat: Marine ritual practice of sasi laut. Paper presented at the IOP Conference Series: Earth and Environmental Science, , 156(1) doi:10.1088/1755-1315/156/1/012039

Yusuf, M., \& Wekke, I. S. (2020). Developing environmental awareness and actualizing complete piety based on quran. International Journal of Advanced Science and Technology, 29(5), 2039-2050.

\section{Biographies}

Muhammad Makbul, a teacher of Islamic Religious Education at the 5 Makassar State Senior High School, as well as a lecturer at the DDI Islamic College of Makassar City, and now continuing his doctoral education at the Alauddin State Islamic University of Makassar. Makbul was born in Baraka, Enrekang, South Sulawesi, Indonesia.

Ismail Suardi Wekke is a lecturer at Postgraduate Program in the Department of Islamic Education, State Islamic Institute (IAIN) Sorong, Indonesia, where he serves as chair (2020-2021). Ismail was born in the village namely Camba. A village in Maros Regency, South Sulawesi, Indonesia. His areas of interest and research range in various topics, including teaching and learning, sociolinguistics, and multicultural education.

Dewi Saputri Sussang, UIN Alauddin Makassar, Indonesia. He also is active in student organization of the faculty. She focuses on the research of education, Islamic education, and teaching and learning. She conducted community services in various location.

Amin Rais, UIN Alauddin Makassar, Indonesia. Served as The President of Student Organization in the faculty. He is also active in the Himpunan Mahasiswa Islam. In addition, he join the komisariat as of the chair for couple years.

Nurlathifah Thulfitrah Baharuddin, UIN Alauddin Makassar, Indonesia. Graduated from Darul Dakwah Wal Irsyad lil Banat Ujung Lare', Parepare. She earned the internship in Thailand. Furthermore, she also completed the community service in Sinjai.

Matahari Muhizar Manaf, Lecturer Universitas Pendidikan Muhammadiyah Sorong, Indonesia. She was the chair of ICOCIT-MUDA 2019. Her field of interest and research concentration is currently focused on issues technology education. 